\title{
Varietal Reaction of Cucumber (Cucumis sativus L.) Germplasm for Management of Fusarium Wilt of Cucumber (FWC)
}

\author{
Ghulam Fareed ${ }^{1}$, Muhammad Atiq ${ }^{1}$, Manzar Abbas', Muhammad Usman', Ghulam Abbas ${ }^{3, *}$, \\ Zulnoon Haidar ${ }^{1}$, Sajid Hussain Qamar ${ }^{4}$ \\ ${ }^{1}$ Department of Plant Pathology, Faculty of Agriculture, University of Agriculture Faisalabad, Pakistan \\ ${ }^{2}$ Centre of Agriculture Biochemistry and Biotechnology, Faculty of Agriculture, University of Agriculture Faisalabad, Pakistan \\ ${ }^{3}$ Department of Poultry Science, Riphah College of Veterinary Sciences, Lahore, Pakistan \\ ${ }^{4}$ Institute of Animal Sciences, University of Agriculture Faisalabad, Pakistan
}

Copyright $\mathrm{C} 2017$ by authors, all rights reserved. Authors agree that this article remains permanently open access under the terms of the Creative Commons Attribution License 4.0 International License

\begin{abstract}
Twelve cucumber varieties/lines (Cuc-30, Cuc-05, Local, Rocky, Hcu-163A, Hashim, Guard HC1, Qasim, Durga, Shaheen, Happy and Green cucumber) were cultivated to find out their genetic potential against Fusarium wilt disease of cucumber in research area of the Department of Plant Pathology University of Agriculture Faisalabad under randomized complete block design (RCBD). None of them was immune and resistant against fusarium wilt of cucumber. Among twelve varieties nine varieties (Green cucumber, Hashim, Rocky, Cu-05, Happy, Durga, Guard HC-1, Cu-30 and Qasim) exhibited moderately susceptible response with $38.0 \%, 37.78 \%, 36.0 \%, 34.0 \%, 31.12 \%$, $28.0 \%, 26.0 \%, 26.0 \%$ and $44.45 \%$ disease incidence respectively. Shaheen $(20.0 \%)$ and Hcu-163A $(22.50 \%)$ expressed moderately resistant response while only one variety (Local) gave highly susceptible reaction with a disease incidence of $55.0 \%$.
\end{abstract}

Keywords Fusarium Wilt, Cucumber Varieties, Screening, Fusarium Wilt Disease

\section{Introduction}

Cucumber (Cucumis sativus L.) is an important economical vegetable of cucerbitaceae family [1]. Cucumber is $4^{\text {th }}$ most important cultivated vegetable after cabbage, onion and tomatoes in the world [2].

It is a main vine crop of Pakistan despite of low cultivation. Its cultivation is increasing gradually due to its medicinal and other valuable aspects. An area of 1200 hectares with a production of 7300 tons was cultivated [3]. Per capita consumption of processed cucumber is $2.2 \mathrm{~kg}$ and of fresh cucumber $3.1 \mathrm{~kg}$ is estimated in United States [3].
A number of biotic and abiotic factors are responsible for its low production. Among biotic factors diseases are the most prominent. Fusarium wilt disease reduces $10-50 \%$ yield significantly in dry and irrigated areas of Pakistan [4]. Wilt pathogen is soil borne and survives in soil for many years and is not controlled by simple methods such as crop rotation [5].

Due to environmental and health concerns nonchemical practices are encouraged over the large use of pesticides and chemicals [6]. It is a fact that presently available genome has a little level of resistance against fusarium wilt disease but, sowing of resistant varieties is cost reducing and environmentally friendly practice. An excellent and reliable way to manage this disease is the finding of resistant genetic potential of germplasm by its own self. This shows cost reduction, efficiency and a friendly behavior to environment so cultivation of resistant genome or cultivar is highly appreciable way to manage the disease over other tools [7]. To suppress the fusarium wilt disease incidence we have no reliable, cost effective, efficient and applicable way till now. However some useful, less expensive and eco-friendly practices are there which are recommended to suppress the pathogen attack one of them is, the use of resistant varieties $[8,9]$. That is why the present study was conducted to find out the resistant germplasm against Fusarium wilt disease of cucumber.

\section{Materials and Method}

A disease screening nursery was established to identify source of resistance against fusarium wilt disease of cucumber in the research area of Department of Plant Pathology, University of Agriculture, Faisalabad in first week of March, 2013. Tewelve cucumber varieties/lines namely Cuc-05, Hcu-163A, Hashim, Cuc-30, Guard HC1, 
Qasim, Rocky, Local, Shaheen, Happy, Durga and Green cucumber were collected from vegetable section of Ayub Agriculture Research Institute (AARI) Faisalabad, and were sown under field conditions with $1 \mathrm{~m} \mathrm{~B} \times \mathrm{B}$ and $30 \mathrm{~cm} \mathrm{P} \times \mathrm{P}$ distance. All the recommended horticultural practices were followed to maintain the crop in good condition. For inoculation, natural inoculum in the form of diseased leaves and seed tubers was collected from vegetable nursery of institute of Horticultural Sciences, University of Agriculture, Faisalabad. These were artificially inoculated by fungus after getting its pure culture in laboratory for pathogenicity test and confirmation of pathogen. On appearance of symptoms, the disease incidence was recorded by using following formula.

$$
\text { Disease Incidence } \%=\frac{\text { No. of infected plants }}{\text { Totalno. of inspected plants }}
$$

(Rahman et al., 2011)[10]

Disease rating was taken on weekly basis to find out the percentage of disease incidences among these cultivars by following the scale of [11].

\begin{tabular}{|c|c|c|}
\hline Scale & Disease incidence & Infection Level \\
\hline 0 & $0 \%$ & Immune \\
1 & $0-10 \%$ & Resistant \\
2 & $11-25 \%$ & Moderately Resistant \\
3 & $26-45 \%$ & Moderately Susceptible \\
4 & $46-70 \%$ & Susceptible \\
5 & $71-100 \%$ & Highly Susceptible \\
\hline
\end{tabular}

Modified Scale [11]

\section{Results}

Table 1. Response of Twelve cucumber germplasm against Fusarium wilt disease

\begin{tabular}{|c|c|c|c|}
\hline $\begin{array}{c}\text { Cultivar/s } \\
\text { varieties }\end{array}$ & $\begin{array}{c}\text { Disease incidence } \\
\text { (\%age) }\end{array}$ & Rating & Response \\
\hline Shaheen & $20 \mathrm{k}$ & 2 & MR \\
\hline Hcu-163A & $22 \mathrm{j}$ & 2 & MR \\
\hline Cuc-30 & $26 \mathrm{i}$ & 3 & MS \\
\hline Guard HC1 & $26 \mathrm{i}$ & 3 & MS \\
\hline Durga & $28 \mathrm{~h}$ & 3 & MS \\
\hline Happy & $31.12 \mathrm{~g}$ & 3 & MS \\
\hline Cuc-05 & $34 \mathrm{f}$ & 3 & MS \\
\hline Rocky & $36 \mathrm{e}$ & 3 & MS \\
\hline Hashim & $37.78 \mathrm{~d}$ & 3 & MS \\
\hline Green cucumber & $38 \mathrm{c}$ & 3 & MS \\
\hline Qasim & $44 \mathrm{~b}$ & 3 & MS \\
\hline Local & $55 \mathrm{a}$ & 4 & HS \\
\hline LSD & & 0.074 & \\
\hline
\end{tabular}

Mean values in a column having similar letters do not differ significantly as determined by LSD test $(\mathrm{P} \leq 0.05)$.

$\mathrm{MR}=$ Moderately Resistant $\mathrm{MS}=$ Moderately Susceptible HS $=$ Highly Susceptible
Fusarium wilt of cucumber appeared in field during the second week of May, 2013 and became maximum in the subsequent weeks till the death of plants. In subsequent weeks of May and June an increase in disease incidence was observed. Leaves and other vegetative parts of cucumber were susceptible to infection by Fusarium oxysporum f.sp. cucumerinum. Symptoms were visible in the form of yellowing of leaves, stunted growth and weakened stem or rottening of vascular tissues. Finally plants were died along fruits. All the cultivated cultivars were almost susceptible to wilt incidence. The maximum disease incidence was noted on Local and was minimum to Shaheen. None of them was immune and resistant against Fusarium wilt of cucumber. Among twelve, nine varieties (Green cucumber, Hashim, Rocky, Cu-05, Happy, Durga, Guard HC-1, Cu-30 and Qasim) exhibited moderately susceptible response with disease incidence of $38.0 \%, 37.78 \%, 36.0 \%, 34.0 \%, 31.12 \%$, $28.0 \%, 26.0 \%, 26.0 \%$ and $44 \%$ respectively. Shaheen $(20 \%)$ and Hcu-163A (22\%) expressed moderately resistant response while only one variety Local gave highly susceptible reaction with a disease incidence 55\% (Table.1).

\section{Discussion}

Present study is an effective tool to manage Fusarium wilt disease caused by pathogen ( $F$. oxysporum f.sp. cucumerinum) of cucumber crop. The plant pathogens produce enzymes and toxin (mode of action) that rupture and degrade the plant cell wall components $[12,13]$. For this purpose the research trial was conducted to screen twelve cucumber varieties/lines, two of them Shaheen and $\mathrm{HCu}-163 \mathrm{~A}$ were moderately resistant cultivars and can be recommended to growers, especially in those areas where the disease is very severe. Moreover, such cultivars can be grown as a source of resistance to develop other wilt resistant varieties, nine varieties were moderately susceptible and one variety was highly susceptible against the disease. On the basis of symptoms data regarding disease incidence showed severe disease symptoms on the Local variety which was categorized into highly susceptible according to scale. Nine cultivars came into the moderately susceptible as the attack was not so severe as Local. Two cultivars expressed minimum disease incidence and categorized as moderately resistant. These results are in agreement with those of Dong and Chen, 1993 [14], Punja and Parker, 2000 [15] and Morsy et al., 2009 [16] reported during their experiment on screening of cucumber cultivars against Fusarium wilt that development of resistant variety is one of the cheapest, safest and durable methods for the control of Fusarium wilt diseases. From Samaria zones numerous descendants experiments were carried to examine the mechanism of resistance, 248 germplasms of many cultivars were sown to assess their own genetic potential to wilt disease attack from them only one susceptible cultivar (Shimson) and numerous cucumber lines or cultivars were assessed. One lonely line WIS-248 was at risk by backcross of parentages. Weizman 
Institute told that Science can manage efficiently the pathogen $F$. oxysporum. This line had given significant behavior of resistance to dominant gene planned to $F$. oxysporum f.sp. cucumerinum [17].

In Sichuan, China 62 cucumber varieties were screened out against fusarium wilt disease to find out the level of resistance. One of them was highly resistant against this disease. Varieties which show white to whitish yellow color showed resistant behavior from green colored cultivars [14].

Screening of 25 cucumber varieties was done against Fusarium wilt disease. Cultivars gave response from highly susceptible to moderately resistant. Serami, Flamingo and Mustang which were known as English cultivars were highly susceptible to wilt pathogen [15].

Four cucumber cultivars Americans IBB, Denmark Beta-Alpha, Americana Beta-Alpha, and Beta-Alpha (Hybrid Japanese) were grown to check them for pathogenicity. All the cultivars were attacked by $F$. oxysporum pathogen [16].

\section{Conclusions}

As minimum disease incidence of Fusarium wilt disease was recorded on variety Shaheen $(20 \%)$. It was scored as moderately resistant (MR) against Fusarium wilt. This variety, because of its good performance against Fusarium wilt disease is recommended for sowing, especially in areas of Fusarium wilt incidence. However, in case the Local variety it is highly susceptible for Fusarium wilt disease incidence, its resistance must be complemented with chemical treatment and by systemic acquired resistance as it does not have resistance against Fusarium wilt disease.

\section{REFERENCES}

[1] D. K. Thoa. Cucumber seed Multiplication and Characterization A.R.C-AVRDC Research Report. Bangkok Thailand, 1998.

[2] N. Shetty, T. C. Wehner. Screening the Cucumber germplasm Collection for Fruit Yield and Quality. Crop Science. 42: 2174-2183, 2002.

[3] GOP. Statistics of Pakistan 2010-11. Government of Pakistan, Ministry of Food, Agriculture and Livestock division. Economic Wing, Islamabad, 2010.

[4] H. Ikramul, F. J. Farhat. Screening of chickpea lines in the wilt sick plot and effect of environmental temperature on wilt incidence. Proceedings of COMSTECH-NIAB International Workshop on Agroclimatology, pests and diseases and their control. November 21-26, 1992, Faisalabad, Pakistan.
[5] R. K. Mujeebur, M. K. Shahana. Effect of root-dip treatment with certain phosphate solubilizing microorganism on Fusarium wilt of tomato. Bio Resources Technology. 85: 213-215, 2002.

[6] R. Reuveni. Novel Approaches to Integrated Pest Management. Lewis Publishers, CRC Press Inc., Boca Raton, FL, 1995.

[7] F. Boyaci, A. Unlu, K. Abak. Screening for resistance to Fusarium wilt of some cultivated eggplants and wild Solanum accessions. International Society for Horticultural Science Acta Horticulturae: 935, 2010.

[8] A. K. Mishra, C. H. Liu, B. He, R. X. Tan. Efficacy of isolantolactone, a sesquiterpenes lactone from Inula racemosa, as herbal fungi toxicant to control 'take-all' disease of wheat. Int. Pest Control 42: 131-137, 2000.

[9] U. Roth, A. Friebe, H. Schnabl. Resistance induction in plants by a brassinosteroid- containing extract of Lychnis viscaria $L$. Zeitschrift fur Naturfor schung section. C. Biosciences. 55: 552-559, 2000.

[10] M. A. Rahman, F. Ali, K. M. A. Hossain. Shoot and Root Growth and Yield of Eggplant Cultivars as Affected by Wilt Disease. Journal of Experimental Sciences. 2: 11-15, 2011.

[11] L. Liu, J. W. Kloepper, S. Tuzun. Induction of systemic resistance in cucumber against fusarium wilt by plant growth-promoting rhizobacteria. Phytopathology 85: 695-698, 1995.

[12] F. G. Moreira, S. D. Reis, M. A. F. Costa, C. G. M. Souza, R. M. Peralta. Production of hydrolytic enzymes by the plant pathogenic fungus Myrothecium verrucaria in submerged cultures. 2005. [Online] Available: http:// www. scielo.br/ scielo.php?pid=s1517-83822005000100002\&script=sci.

[13] N. D. Omokolo, D. J. Nankeu, N. Niemenak, T. Boudjeko. Variation of $\beta$-1, 3-glucanase, chitinase and polyphenoloxidase activities on cacao pods upon Phytophthora megakarya inoculation. African Crop Science 11: 97-106, 2003.

[14] W. Dong, L. Chen. Identification of resistance to fusarium wilt in Sichuan cucumber cultivars. Cr. Gent. Resourc. 3: 16, 1993.

[15] Z. K. Punja, M. Parker. Development of Fusarium root and stem rot, a new disease on greenhouse cucumbers in British Columbia caused by Fusarium oxysporum f.sp. radices-cucumerinum. Can. J. Plant Pathol. 22: 349-363, 2000.

[16] S. M. Morsy, E. A. Drgham, G. M. Mohammad. Effect of Garlic and Onion Extracts or their Intercropping or Suppressing Damping-off and Powdery Mildew Diseases and Growth Characteristics of Cucumber. Egypt. J. Phytopathol. 37: 35-46, 2009.

[17] D. Netzer, S. Niego, E. Galun. A Dominant Gene Conferring Resistance to Fusarium wilt in Cucumber. Phytopathology. 67: 525-527, 1976. 